\title{
Risk factors associated with unwanted pregnancy in female
} medical students

\author{
Diana Patricia Vanegas-Coveña, ${ }^{\text {* }}$ Tesifón Parrón-Carreño, ${ }^{2}$ Cayetano Aranda-Torres ${ }^{2}$ and \\ Raquel Alarcón-Rodríguez ${ }^{2}$ \\ ${ }^{1}$ Universidad de Cuenca, Faculty of Medical Sciences, Cuenca, Ecuador; ${ }^{2}$ Universidad de Almería, Almería, Spain
}

\begin{abstract}
\end{abstract}
Introduction: Most pregnancies in adolescents and young adults are unwanted and many are the consequence of inconsistent contraception use. Objective: To analyze the risk factors that may influence on female adolescents with unwanted pregnancies. Method: Cross-sectional, descriptive study in Ecuadorian female medical students, where the 2013 National Sexual and $\mathrm{Re}$ productive Health Survey, the family APGAR scale, and the Graffar-Méndez Castellanos socio-economic scale were used. Results: There was statistically significant difference in the age of active sexual life initiation between those who became pregnant (18.11 \pm 1.45 ) and those who did not (19.22 \pm 2.28 ). Average age at pregnancy was $20.41 \pm 2.18 ; 59.3 \%$ of those who had a pregnancy and $32 \%$ of those without pregnancy did not use protection in their first intercourse. Pregnancy was more common in city residents (100\%), Catholic females (85.2\%), who belonged to middle-high (55.6 \%) and middle socioeconomic strata (29.6\%) and to families with moderate dysfunction (40.7\%). Conclusions: A significant percentage of a dolescents in our study had an unwanted pregnancy at an early age despite being young undergraduate medical students, coming from moderately dysfunctional families and belonging to a middle-high socioeconomic status.

KEY WORDS: Medical students. Pregnancy. Contraception. Family functionality. Socioeconomic stratum.

\section{Introduction}

Sexuality is a broad concept that encompasses interests, behaviors, functioning, satisfaction, intimate relationships and sexuality self-perception. Historically, it has been considered within a biomedical context, with an emphasis on the sexual response cycle, as well as on heteronormative and heterosexist behaviors. A comprehensive view should include the emotional, social and intellectual aspects. Conversely, somatic experiences represent diverse sexual experiences and focus on pleasure. ${ }^{1}$

Among adults, little is spoken about adolescent sexuality, since addressing the subject is considered to be a trigger for unleashing sexual acts. It remains a taboo, which is reproduced through silence, myths and negative emotions; consequently, the possibility of its open and comprehensive approach from a perspective of rights is low, which negatively impacts on adolescent pregnancy prevention. ${ }^{2}$

Studies on sexual behaviors in students of the Polytechnical Higher School of Chimborazo, Ecuador, found that $46.24 \%$ of women started their active sex life at an average age of 18 years; $52.33 \%$ did notuse contraceptive methods during their first intercourse.

In a study in Cuenca, Ecuador, sexual active life onset and the possibility of early pregnancy were considered to be an obstacle to reaching socioeconomic independence, in a society where early pregnancy is linked to the cycle of poverty. ${ }^{4,5}$

Childbirths in young females of between 15 and 19 years of age account $11 \%$ of worldwide childbiths, approximately 16 million every year. ${ }^{6}$ Adolescents have disproportionately high morbidity rates derived
Correspondence:

*Diana Patricia Vanegas-Coveña

E-mail: diana.vanegas@ucuenca.edu.ec
Date of reception: 01-09-2018

Date of acceptance: 19-03-2019

DOI: 10.24875/GMM.M19000298 
from their sexual behavior, including sexually transmitted infections and unwanted pregnancies.?

In Portugal, $14.7 \%$ of adolescent pregnancies were observed. ${ }^{8}$

In developing countries, $43 \%$ of pregnancies are unplanned and are more prevalent in poor, rural women with low educational level. Every year, 89 million unplanned pregnancies and 48 million abortions occur. ${ }^{9,10}$ In one study in Colombia, adolescent pregnancy was associated with poverty, low educational level and school dropout, with social class, economic and social inequality persisting as structural determinants. ${ }^{11}$ In France and Great Britain, surveyed subjects of higher socioeconomic groups had lower probabilities of pregnancy before 20 years of age..$^{2}$

In Latin America and the Caribbean, pregnancy in adolescents is a public health priority, since it ranks second in the world, after Sub-Saharan Africa. Ecuador is the third country in the region with the highest adolescent pregnancy rate, after Nicaragua and the Dominican Republic. . $^{13,14}$

In recent years, particularly in Ecuador, the perception on pregnancy, family transformation and the conception of adolescence as a social group have changed, which affects pregnancy at this stage of life and perpetuates the circle of violence, poverty and interrupted educational processes. ${ }^{15}$

Most pregnancies in adolescents and young adults are involuntary, and many are a consequence of inconsistent contraception use. ${ }^{6}$

Numerous female adolescents conceive their life projects within marriage and motherhood; in those cases, pregnancy can be experienced as an escape or solution rather than as a problem. ${ }^{2}$

Family functionality, as well as cultural, biological, religious, emotional and environmental factors influence on adolescent sexual decisions, which underlines the importance of family in sexual and reproductive health throughout the world. ${ }^{16}$ Freud stated: "childhood is destiny", since our relationship with the world will depend on our first personal relationships. In a functional family, conflicts are lived as a difference of opinions between family members and do not threaten family stability; in a dysfunctional family, conflict is perceived as a challenge to authority and as a risk for destabilization of the system and, therefore, it is avoided or repressed. ${ }^{17}$ In Colombia, family dysfunctionality was found to be a factor related to early motherhood; ${ }^{10,18}$ similar results were obtained in Ecuador in $2013^{19}$ and in Mexico, with $50.8 \%$ of unwanted pregnancies in adolescents coming from dysfunctional families. ${ }^{20}$
The number of undergraduate students who use a condom at first sexual encounter is low, and it decreases as they move forward in their sexual life

In the CERCA project of Cuenca, Ecuador, most sexually active adolescents were observed to systênatically fail to use contraceptives. ${ }^{22}$ Another study in Cuenca recorded that $90 \%$ of adolescents knew about contraceptive methods; however, $70 \%$ stated that their use was not frequent. ${ }^{23}$ Despite initial use of some contraceptive method, $51.9 \%$ of female adötescents reported having been pregnant sometime. ${ }^{24}$

Among students from the Netherlands, the prevalence of condom use in the last sexual encounter was $68.2 \%$, and for the pill, it was $65.2 \% .^{25}$

Based on the aforementioned works, where a . high number of unwanted pregnancies has been found to be a social issue that requires urgent attention, and where dysfunctional family relationships and poverty levels have been associated, this study was carried out to analyze the possible factors that may influence on unwanted pregnancies in students of the Cuenca universities.

\section{Objective}

The main goal of the study was to analyze the risk factors that may influence on female adolescents with unwanted pregnancies.

\section{Method}

A descriptive cross-sectional study was conducted in female medical internship students (year of pre-professional practical training) from all universities of Azuay, Ecuador (University of Cuenca, Catholic Üniversity of Cuenca, University of Azuay).

The study population consisted of 127 women enrolled during the 2016-2017 academic year in all universities of Azuay and who had started having an active sex life. Those who had not yet started active sexual life were excluded from the study. For data collection, the 2013 National Survey of Sexual andReproductive Health, from the Ministry of Health of Argentina, for women, was used. Sociodemographic information was also collected (age, place of residence, religion), as well as variables related to sexual intercourse (age of onset, intercourse voluntary nature, use of contraceptive methods, unwanted pregnancy).

To establish the degree of family functionality, cthe family APGAR scale was used, which shows how family members globally perceive the functioning of the family unit. ${ }^{26}$ This tool was designed in 1978 by 
Table 1. Comparison of sociodemographic characteristics in women who have had a pregnancy or not

\begin{tabular}{|c|c|c|}
\hline \multirow{3}{*}{ Variables } & \\
\hline & \multicolumn{2}{|c|}{ Yes } \\
\hline & \multicolumn{2}{|c|}{ Mean \pm SD } \\
\hline Age & 27 & $24.96 \pm$ \\
\hline & $n$ & $\%$ \\
\hline $\begin{array}{l}\text { Religion } \\
\text { Catholic } \\
\text { Non-Catholic } \\
\text { Atheism }\end{array}$ & $\begin{array}{c}23 \\
3 \\
1\end{array}$ & $\begin{array}{l}85 . \\
11 . \\
3.7\end{array}$ \\
\hline $\begin{array}{l}\text { Place of residence } \\
\text { Urban } \\
\text { Rural }\end{array}$ & $\begin{array}{c}27 \\
0\end{array}$ & $\begin{array}{r}10 \\
0\end{array}$ \\
\hline $\begin{array}{l}\text { Socioeconomic stratum } \\
\text { I High } \\
\text { II Middle-high } \\
\text { III Middle } \\
\text { IV Middle-low } \\
\text { V Low }\end{array}$ & $\begin{array}{c}0 \\
15 \\
8 \\
4 \\
0\end{array}$ & $\begin{array}{r}0 \\
55 . \\
29 . \\
14 . \\
0\end{array}$ \\
\hline $\begin{array}{l}\text { Family functionality } \\
\text { Normal } \\
\text { Mild dysfunction } \\
\text { Moderate dysfunction } \\
\text { Severe dysfunction }\end{array}$ & $\begin{array}{c}3 \\
6 \\
11 \\
7\end{array}$ & $\begin{array}{l}11 . \\
22 . \\
40 . \\
25 .\end{array}$ \\
\hline
\end{tabular}

doctor Gabriel Smilkstein (Washington), who proposed it as an instrument for primary care teams, in their approach to family function analysis. The family APGAR evaluates five basic functions of the family (adaptation, participation, personal resource gradient, affection and resources). ${ }^{27}$

This scale was validated by Bellon et al. in 1996. Its internal consistency was good, with a Cronbach alpha of $0.770 .{ }^{28}$ The degree of family functionality is interpreted as follows:

- Normal, 17 to 20 points.

- Mild dysfunction, 16 to 13 points.

- Moderate dysfunction, 12 to 10 points.

- Severe dysfunction, $\leq 9$ points.

The instrument used to measure the socioeconomic level was Graffar-Méndez Castellanos scale, which has four dimensions: head of the family occupation, maternal level of education, source of income and housing conditions. It was validated at the Autonomous University of Mexico with Cronbach's alpha (reliability of 0.69). ${ }^{29,30}$ Each variable has five categories with progressive scores. A final score classifies subjects into five categories: ${ }^{31,32}$

- High socioeconomic level (I), 4 to 6 points.

- Middle-high socioeconomic level (II), 7 to 9 points.
Pregnancy

No

Mean \pm SD

n

$23.75 \pm 1.31$

$<0.01 \times$

n

$\%$

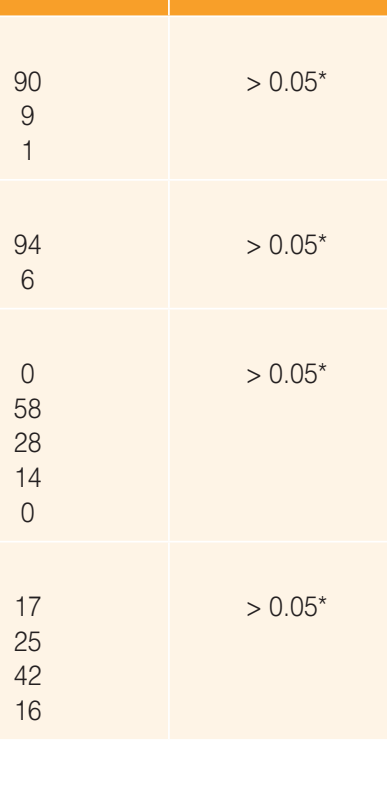

- Middle socioeconomic level (III), 10 to 12 points.

- Middle-low socioeconomic level (IV), 13 to 16 points.

- Low socioeconomic level (V), 17 to 20 points.

For statistical management, the statistical program SPSS, version 22, was used. Univariate analysis was performed: for qualitative variables, frequencies were calculated with their respective percentages, and for quantitative variables, mean \pm standard deviation.

For the comparison of qualitative variables, the chisquare test was used, for a statistical significanee of $p<0.05$; for the comparison of quantitative variables, Mann-Whitney's U-test was used.

\section{Results}

The participants were 127 undergraduate females, with an average age of $24 \pm 1.86$ years at the time of the study; $21.2 \%$ had had an unwanted pregnancy (UWP).

Table 1 describes the participants' sociodemographic characteristics, depending on whether they had had an UWP or not. Of the women who had $\overline{\text { had }}$ an UWP, $85 \%$ were Catholic, as well as $90 \%$ of those who had not. All the women who had had an ÜWP and $94 \%$ of those who had not, resided in the urban sector. 
Table 2. Comparison of sociodemographic characteristics of women who have had a pregnancy or not

\begin{tabular}{|c|c|c|c|c|c|c|}
\hline \multirow[t]{3}{*}{ Variables } & \multicolumn{4}{|c|}{ Pregnancy } & \multirow[t]{3}{*}{$p$} & $\simeq$ \\
\hline & \multicolumn{2}{|c|}{ Yes } & \multicolumn{2}{|c|}{ No } & & $\gtrsim$ \\
\hline & $\mathrm{n}$ & Mean \pm SD & $\mathrm{n}$ & Mean \pm SD & & E \\
\hline Age at first sexual encounter & 27 & $18.11 \pm 1.45$ & 100 & $19.22 \pm 2.28$ & & $01 \times$ \\
\hline Age at which she had the first couple & 27 & $19.78 \pm 3.40$ & 100 & $21.87 \pm 3.04$ & $<0.0$ & $01^{*}$ \\
\hline \multirow[t]{2}{*}{ Age at pregnancy } & 27 & $20.41 \pm 2.18$ & & & & $\stackrel{ \pm}{c}$ \\
\hline & $\mathrm{n}$ & $\%$ & $\mathrm{n}$ & $\%$ & & 응 \\
\hline $\begin{array}{l}\text { Voluntary nature of first intercourse } \\
\text { Voluntary } \\
\text { Not voluntary }\end{array}$ & $\begin{array}{c}20 \\
7\end{array}$ & $\begin{array}{l}74.1 \\
25.9\end{array}$ & $\begin{array}{l}75 \\
25\end{array}$ & $\begin{array}{l}75 \\
25\end{array}$ & & $05^{\circ}$ \\
\hline $\begin{array}{l}\text { Relationship with first sexual partner } \\
\text { Friend, neighbor, acquaintance } \\
\text { Boyfriend } \\
\text { Spouse/roommate }\end{array}$ & $\begin{array}{c}0 \\
27 \\
0\end{array}$ & $\begin{array}{c}0 \\
100 \\
0\end{array}$ & $\begin{array}{c}6 \\
91 \\
3\end{array}$ & $\begin{array}{c}6 \\
91 \\
3\end{array}$ & & $05 \frac{c}{\frac{0}{n}}$ \\
\hline $\begin{array}{l}\text { Contraceptives at first intercourse } \\
\text { Yes } \\
\text { No }\end{array}$ & $\begin{array}{l}11 \\
16\end{array}$ & $\begin{array}{l}40.7 \\
59.3\end{array}$ & $\begin{array}{l}68 \\
32\end{array}$ & $\begin{array}{l}68 \\
32\end{array}$ & & 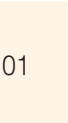 \\
\hline
\end{tabular}

The Graffar Méndez Castellanos socioeconomic scale results showed that $55.6 \%$ of women with UWP belonged to middle-high and $29.6 \%$ to middle socioeconomic status; with $14.8 \%$ corresponding the middle-low level. There were no women of the high or low strata with UWP. Among the women who had not had any pregnancy, $58 \%$ belonged to the middle-high stratum, $28 \%$ to the middle stratum and $14 \%$ to the low stratum. These results showed no statistically significant differences between adolescent girls who had had an UWP and those who had not had any pregnancy.

As regards the APGAR family functionality scale, $40.7 \%$ of the adolescents who had had an UWP came from families with moderate dysfunctionality, $25.9 \%$ had families with severe dysfunctionality, $22.2 \%$ with mild dysfunctionality and $11.1 \%$ came from functional families. Of the students who had had no pregnancy, $42 \%$ came from families with moderate dysfunction, $25 \%$ from families with mild dysfunction, $16 \%$ from families with severe dysfunction and $17 \%$ came from functional families. These results showed no statistically significant differences (Table 1).

Adolescents who had had an UWP had her first sexual encounter at the age of $18.11 \pm 1.45$ years and those who had not had any pregnancy at $19.22 \pm 2.28$ years, with statistically significant results. Mean age of the adolescents when they got pregnant was $20.41 \pm 2.18$.

Approximately $25 \%$ of adolescents, both those who had had an UWP and those who had not, indicated that their first sexual encounter had not been voluntary.
All adolescent girls who had had an UWP and 99 of those without a history of pregnancy had their first sexual intercourse with their boyfriend.

As for the use of contraceptive methods, $59.3 \%$ of adolescents who had had an UWP and $32 \%$ without this history indicated not having used contraceptive methods on their first sexual encounter, which wasan issue that showed statistically significant differences (Table 2).

The reasons of women with UWP for not using contraceptives on their first sexual intercourse were that their partner refused to $(36.8 \%)$, the belief of not getting pregnant $(26.3 \%)$ and ignorance $(21.1 \% \%)$. Women who had not had a pregnancy pointed out as causes that their partner did not want to $(45.3 \% \%)$, ignorance (17\%) and the belief of no getting preghant $(17 \%)$. No statistically significant differences were identified.

\section{Discussion}

At the Azuay universities that offer the medical-degree, among 127 participant females, the frequency of UWP was $21.2 \%$. These figures are similar to those described in 2014 by the United Nations Children's Fund, with $20 \%$ of pregnant young females in Eatin America and the Caribbean; ${ }^{2}$ as well as to figures found in 2013 by Zhou in Chinese female students, where the prevalence was $19.8 \%{ }^{33}$ and by Morales, in Cuba, with a prevalence of $18.7 \%{ }^{34}$ 
In contrast, our results differ from others that show higher figures, such as the study by Shu in China in 2016 , where $34.03 \%$ was recorded,,$^{35}$ or the trial carried out by Ariza, in 2014, in young Colombian females, which showed UWP figures of $32.3 \%{ }^{\cdot 10}$ in 2015, Wang found $31.8 \%$ in China ${ }^{36}$ In another work carried out in Spain by Yago in 2014, the prevalence of UWP was $29.8 \%{ }^{37}$

Other studies, such as the one conducted by Xiao Ming in China (2013), showed lower UWP data than those obtained in ours $(15.1 \%){ }^{38}$ Coronado, in an investigation carried out in Spain indicated $1 \%$ in female medical students. ${ }^{39}$

In our study, $18.5 \%$ of women who indicated having a history of pregnancy had aborted. These data are similar to those reported by Scott (2017): $18 \%$ of adolescents who became pregnant also aborted. ${ }^{12}$ In 2016, Shu described a very different scenario: $96.7 \%$ of adolescents in this situation used to abort..$^{33}$ In that same year, Coronado recorded that $40 \%$ of female adolescent medical students that got pregnant had an abortion. ${ }^{39}$

Adolescents who had had an UWP belonged to middle-high and middle socioeconomic strata (55.6 and $29.6 \%$, respectively). These results differ from those obtained by Blanco in 2015, in Venezuela, according to which extreme and non-extreme poverty were risk factors for UWP. ${ }^{40}$ The study carried out by Scott in 2017 in France and Great Britain, showed that UWP practically did not occur in adolescent girls belonging to high and middle socioeconomic strata. ${ }^{12}$

In our study, female adolescent who had had an UWP came mostly from families with moderate dysfunction. Similar results were reported by Soto in a study in Mexico, where family functionality was normal in adolescents with UWP. ${ }^{20}$ The above-mentioned findings differ from those of Blanco in Venezuela, who associated pregnancy with severe dysfunctionality. ${ }^{40}$ Results obtained by Ariza and Betancur in Colombia, indicate that a dysfunctional or conflictive family is a risk factor for UWP..$^{10,18}$ In 2013, Aquino published a study on Ecuadorian adolescents that revealed that family problems and family abuse predisposed to UWP. ${ }^{19}$

Average age at first sexual intercourse among the female students who had an UWP was $18.11 \pm$ 1.45 years, which is consistent with the results referred by Zhou in China, which show that the younger the age of sexual debut, the higher the risk of UWP. ${ }^{33,35}$ Okigbo and Panova, in 2015 and 2016, found a relationship between UWP and age of sexual debut younger than 15 years. ${ }^{41,42}$
In our study, $59.3 \%$ of female adolescents who had had an UWP had not used contraceptives on first intercourse. These data are consistent with those reported in Zhou studies and Shu studies. ${ }^{33,35}$ In a study conderted in Mexico, $100 \%$ of pregnant female adolescênts recognized the lack of contraceptive use on theirfirst sexual intercourse as the cause of their UWP. ${ }^{43}$

In conclusion, a significant percentage of female adolescents in our study, despite being young medical students, coming from families with a moderate degree of functionality and middle-high socioeconomic status, had had an unwanted pregnancy at an early age.

\section{Acknowledgements}

Our most sincere appreciation to the young women of the University of Cuenca, Catholic University of Cuenca and Azuay University, for their unconditional collaboration, which made the performance of this study possible.

\section{References}

1. Syme M. The evolving concept of older adult sexual behavior and its benefits. Generations. 2014;38:35-41.

2. Fondo de las Naciones Unidas para la Infancia. Vivencias y relatos'sobre el embarazo en adolescentes. Una aproximación a los factores culturales, sociales y emocionales a partir de un estudio en seis países de la región. Informe final. Panamá: UNICEF; 2014.

3. Saeteros-Hernández RC, Pérez-Piñero CJ, Sanabria-Ramos CG. Vivencias de la sexualidad en estudiantes universitarios. Rev Cuba Salud Publica. 2013;39:915-928.

4. Núñez-Castillo J, Derluyn I, Valcke M. Young people's expressed needs for comprehensive sexuality education in Ecuadorian schools. Sex Egduc. 2018;18:14-31.

5. Jerves E, López S, Castro C, Ortiz W, Palacios M, Rober P, et af, Understanding parental views of adolescent sexuality and sex educafion in Ecuador: a qualitative study. Sex Educ. 2014;14:14-27.

6. Society for Adolescent Health and Medicine. Improving knowledge about, access to, and utilization of long-acting reversible contraception among adolescents and young adults. J Adolesc Health. 2017;60:472-474.

7. Corona HF, Funes DF. Abordaje de la sexualidad en la adolescencia. Rev Med Clin Las Condes. 2015;26:74-80.

8. Mendes N, Palma F, Serrano F. Sexual and reproductive health afPortuguese adolescents. Int J Adolesc Med Health. 2014;26:3-12.

9. United Nations Population Foundation [sitio web]. State of World PopuIation 2017 EE. UU.: United Nations Population Foundation; 2017

10. Ariza-Riaño NE, Sanabria MLV, Díaz JMO. Caracterización del embarazo adolescente en dos ciudades de Boyacá, Colombia. Rev VirtuabUniv Catolica Norte. 2014;42:154-63.

11. Arias RM, Arias NA. Maternidad adolescente, desigualdad social $\bar{y}$ exclusión educativa en el Norte de Santander (Colombia) y Táchira ( Venezuela). Espac Abierto Cuad Venez Sociol. 2017;26:121-138.

12. Scott RH, Bajos N, Slaymaker E, Wellings $\mathrm{K}$, Mercer $\mathrm{CH}$. Understånding differences in conception and abortion rates among under-20 yearrolds in Britain and France: examining the contribution of social disadvanfage. PloS One. 2017;12:e0186412.

13. Ministerio de Salud Pública del Ecuador. Plan Nacional de Salud Segual y Salud Reproductiva 2017-2021. Ecuador: Ministerio de Salud Püblica del Ecuador; 2017.

14. Rodríguez-Vignoli J. La reproducción en la adolescencia y sus destgualdades en América Latina. Introducción al análisis demográfico, cợn énfasis en el uso de microdatos censales de la ronda de 2010. CChile: Comisión Económica para América Latina y el Caribe; 2014.

15. Burneo-Salazar C, Córdova-Páez A, Gutiérrez MJ, Ordóñez A. Emb̄arazo adolescente en el marco de la Estrategia Nacional Intersectofial de Planificación Familiar (ENIPLA) 2014 y el Plan Nacional de Fortalecimiento de la Familia 2015 [sitio web]. Ecuador: Montecristi Vive; 2015. 
16. Adebayo AM, Ajuonu EJ, Betiku BO. Family functionality and parental characteristics as determinants of sexual decision-making of in-school youths in a semi-urban area of Southwest Nigeria. Int J Adolesc Med Health. 2016;28:413-418.

17. Canales J. Padres tóxicos. Legado disfuncional de una infancia. México: Paidós; 2014

18. Rojas-Betancur M, Méndez-Villamizar R, Álvarez-Nieto C. El papel de la familia en la normalización del embarazo a temprana edad. Rev Encuentros. 2016;14:139-150.

19. Aquino R, Jacqueline V. Incidencia del embarazo en la adolescencia en mujeres de 12 a 18 años en Maternidad Mariana de Jesús de septiembre 2012 a febrero del 2013. [Tesis de pregrado]. Ecuador: Universidad de Guayaquil; 2013

20. Soto-Acevedo F, Alberto León-Corrales I, Castañeda-Sánchez O. Calidad de vida y funcionalidad familiar en adolescentes embarazadas derechohabientes de una unidad de medicina familiar del estado de Sonora, México. Aten Fam. 2015;22:64-67.

21. Baiz JB, Morales FM, Pereyra LP. Aspectos psicosociales de la salud sexua y reproductiva en estudiantes universitarios. Salud Soc 2016:7:180-195.

22. Córdova-Pozo K, Chandra-Mouli V, Decat P, Nelson E, De Meyer S Jaruseviciene $\mathrm{L}$, et al. Improving adolescent sexual and reproductive health in Latin America: reflections from an International Congress. Reprod Health. 2015;12:11.

23. González-Rugel E, Ortega-Mendoza WG. Percepciones sobre maternidad y paternidad en adolescentes hombres y mujeres, el caso de cuatro colegios del cantón Cuenca, período 2009-2010. [Tesis de pregrado]. Ecuador: Universidad de Cuenca; 2013.

24. Sam-Soto S, Osorio-Caballero M, Rodríguez-Guerrero R, Pérez-Ramírez N. Comportamiento sexual y anticoncepción en la adolescencia. Acta Pediatr Mex. 2014;35:490-498

25. De Looze M, Constantine NA, Jerman P, Vermeulen-Smit E, Bogt T Parent-adolescent sexual communication and its association with adolescent sexual behaviors: a nationally representative analysis in the Netherlands. J Sex Res. 2015;52:257-268.

26. Yaphe J. Is the family APGAR dead? A reappraisal of family assessment tools in Portugal. Rev Port Med Geral E Fam. 2013;29:14-15.

27. Cuba-Suárez AM, Alcalá-Espinoza M. APGAR familiar: una herramienta para detectar disfunción familiar. Rev Med La Paz. 2014;20:53-57.

28. Gómez-Clavelina FJ, Ponce-Rosas ER. Una nueva propuesta para la interpretación de Family APGAR (versión en español). Aten Fam. 2010; 17:102-106.

29. Benítez-Mesa M, Dunia-Dahdah MR, Rodríguez-Morales AJ. Evaluación del método de estratificación social Graffar-Méndez Castellano. 2011.
30. Cardozo Castellano de A RA, Poveda de Agustín JM, Guevara Rivas H, Ortunio Calabrés M, Loaiza Borges L, Torres San Narciso E. Características socio-demográficas de estudiantes de Medicina de dos Oniversidades Públicas en España y en Venezuela. 2009-2010. Zitae. 2013:54:1-5

31. Millán A, D'Aubeterre ME, Calvanese N. Propiedades psicométricas de la escala de preferencias vespertinidad/matutinidad en una muestra multiocupacional de trabajadores venezolanos. Rev Cuba Salud Trab. 2012:13:37-49.

32. Mendoza-Pinto C, Méndez-Martínez S, Soto-Santillán P, Galindo-Herrera J, Pérez-Contreras I, Macías-Díaz S, et al. Socioeconomic status and organ damage in Mexican systemic lupus erythematosus women. Eupus. $2015 ; 24: 1227-1232$

33. Zhou Y, Xiong C, Xiong J, Shang X, Liu G, Zhang M, et al. A blind"area of family planning services in China: unintended pregnancy among unmarried graduate students. BMC Public Health. 2013;13:198.

34. Morales-Díaz E, Rojas S, María A, González M, Roberto S, Miranđāa-Gómez O. Embarazo no deseado en alumnas universitarias. Rev CubäMed Mil. 2013;42:153-163.

35. Shu C, Fu A, Lu J, Yin M, Chen Y, Qin T, et al. Association between age at first sexual intercourse and knowledge, attitudes and practices regarding reproductive health and unplanned pregnancy: a cross-sectional study. Public Health. 2016:135:104-113.

36. Wang $\mathrm{H}$, Long L, Cai $\mathrm{H}, \mathrm{Wu} \mathrm{Y}, \mathrm{Xu} \mathrm{J}$, Shu $\mathrm{C}$, et al. Contraception and unintended pregnancy among unmarried female university students. a cross-sectional study from China. PLoS One. 2015;10:e0130212.

37. Yago-Simón T, Tomás-Aznar C. Variables sociodemográficas relacionadas con embarazos no planificados en jóvenes de 13 a 24 años. Rev Esp Salud Publica. 2014;88:395-406.

38. Yu XM, Guo SJ, Sun YY. Sexual behaviours and associated risks in Chinese young people: a meta-analysis. Sex Health. 2013;10:424-433.

39. Coronado-Martin P, Delgado-Miguel C, Rey-Cañas A, A. Herrå̉z M. Sexual and reproductive health in Spanish university students. A'comparison between medical and law students. 2017:11:97-101.

40. Blanco L, Cedre O, Guerra ME. Factores determinantes del embarazo adolescente. Odontol Pediatr Lima. 2015;14(2):109-119.

41. Okigbo CC, Speizer IS. Determinants of sexual activity and pregnancy among unmarried young women in urban Kenya: a cross-sectional study. PLoS One. 2015;10:1-17.

42. Panova OV, Kulikov AM, Berchtold A, Suris JC. Factors associatedt with unwanted pregnancy among adolescents in Russia. J Pediatr Adolesc Gynecol. 2016;29:501-505.

43. Otero LMR. El embarazo a temprana edad. Perspectiva de progenifores y madres adolescentes. Rev Sobre Infancia Adolesc. 2016:10:81.107. 